\title{
KONSEP MANUSIA DAN IMPLEMENTASINYA DALAM PERUMUSAN TUJUAN PENDIDIKAN ISLAM MENURUT MURTADHA MUTHAHHARI
}

\author{
SAIHU \\ Institut PTIQ Jakarta \\ madesaihu@ptiq.ac.id
}

\begin{abstract}
Abstrak
Manusia menurut Murtadha Muthahhari adalah makhluk yang sangat unik, memiliki kecerdasan tanggung jawab dan makhluk yang rasional. Manusia dilahirkan dengan keadaan tidak tahu apapun akan tetapi Allah memberi manusia kelebihanya itu dengan pendengaran, pengelihatan, akal dan hati yang digunakan untuk membekali kehidupannya menjadi manusia yang baik dan bersyukur. Dengan itu manusia dapat beribadah, bertakwa kepada Tuhannya dan berbakti kepada-Nya yaitu dengan mengabdikan kemampuannya di dunia ini itulah yang dinamakan manusia sempurna. Konsep manusia ini tercermin pada rumusan tujuan pendidikan bahwa tujuan pendidikan itu manusia yang sempurna dengan cara melatih jiwa, akal, pikiran, perasaan dan fisik manusia dengan demikian, pendidikan harus mengupayakan tumbuhnya seluruh potensi manusia baik yang bersifat spiritual, intelektual, daya khayal, fisik, ilmu pengetahuan, maupun bahasa baik secara individual maupun kelompok. Melalui akal dan qalbu yang telah diberikan oleh Allah dan dengan pendidikan yang diterima manusia akan mampu bersosialisasi dengan orang lain untuk memenuhi kebutuhan hidupnya. Selanjutnya metode penelitian yang digunakan adalah metode penelitian kualitatif dengan pendekatan deskriptif analisis dan kajian pustaka. Setelah data terkumpul dan tercatat dengan baik, maka langkah selanjutnya adalah menganalisa data.
\end{abstract}

Kata Kunci: Manusia, Pendidikan, Akal, Qalbu

Abstract

Humans, according to Murtadha Mutahhari, are very unique creatures, possessing intelligent intelligence and rational beings. Humans are born with a state of not knowing anything but God gives the human excess with hearing, sight, mind and heart which are used to equip his life to be a good and grateful human being. With that, humans can worship, devote to their Lord and worship Him by dedicating their abilities in this world to what is called perfect man. This human concept is reflected in the formulation of educational goals that the purpose of education is a perfect human being by training the soul, mind, mind, feelings and physical humanity thus, education must strive for the growth of all human potential both spiritual, intellectual, imaginative, physical, science, and language both individually and in groups. Through reason and heart that has been given by God and with education received by humans will be able to socialize with others to meet their needs. Furthermore, the research method used is a qualitative research method with a descriptive approach to analysis and literature review. After the data is collected and recorded properly, the next step is to analyze the data.

Keywords: Human, Education, Intellect, Qalbu 


\section{A. PENDAHULUAN}

Konsep adalah rancangan, ide atau pengertian yang diabstrakan dari peristiwa konkret. ${ }^{1}$ Menurut J. Sudaminta, konsep secara umum dapat dirumuskan pengertiannya sebagai suatu representasi abstrak dan umum tentang sesuatu, dan sebagai representasi abstrak dan umum tentu saja konsep merupakan suatu hal yang bersifat mental, representasi sesuatu itu terjadi dalam pikiran. Konsep yang merupakan hasil abstraksi pikiran manusia dari objek dialami secara indrawi. Konsep juga dapat dimengerti dari sisi subjek maupun sisi objek. Dari sisi subjek konsep adalah kegiatan merumuskan dalam pikiran atau rancangan, sedangkan dari sisi objek konsep adalah isi dari kegiatan tersebut.

Manusia adalah salah satu dari sekian banyak makhluk ciptaan Tuhan yang diberikan banyak kelebihan dari makhluk yang lain, selain karena keistimewaannya manusia juga makhluk yang unik dan utuh. Manusia sebagai makhluk filosofis memang tidak ada habisnya dibahas oleh para pemikir dari zaman Yunani sampai zaman sekarang. Kerumitan organisasi tubuhnya beserta substansi non material yang imanen dalam dirinya yang sulit di terjemahkan oleh nalar menjadi penegas bahwa mendeskripsikan manusia bukanlah perkara mudah. Tidaklah salah ketika manusia diposisikan sebagai makhluk misterius. Namun pada posisi itu pula manusia menjadi kajian yang menarik untuk dibahas dan hampir semua lembaga pendidikan tinggi mengkaji tentang manusia, karya dan dampak karyanya terhadap dirinya sendiri, masyarakat dan lingkungan hidupnya. ${ }^{2}$

Secara bahasa, manusia disebut Insan, di mana dalam bahasa arabnya berasal dari kata Nasiya yang berarti lupa, dan jika dilihat dari kata dasarnya, al-Uns berarti jinak. Kata insan dipakai untuk menyebut manusia, karena manusia memiliki sifat lupa dan kata jinak dipakai karena mempunyai arti di mana manusia selalu menyesuaikan diri dengan keadaan baru disekitarnya. ${ }^{3}$ Para ahli telah mengkaji manusia menurut bidang studinya masing-masing, tetapi sampai sekarang para ahli masih belum mencapai kata sepakat tentang manusia. Ini terbukti dari banyaknya nama lain tentang manusia, misalnya homo sapien (manusia berakal), homo economicus (manusia ekonomi), yang kadang disebut economi animal (binatang ekonomi). Dipandang sudut biologi, manusia hanya merupakan suatu macam makhluk di antara lebih dari sejuta macam makhluk lain yang pernah atau masih menduduki alam dunia ini. ${ }^{4}$

Definisi manusia yang cukup populer menyebutkan manusia adalah hewan yang berpikir (al-insan hayawan al-natiq). ${ }^{5}$ Manusia adalah satu-satunya makhluk yang diciptakan dengan segala kelebihan dengan makhluk lain, secara fisik maupun spirit, jasmani maupun rohani, sedangkan dari segi lahiriah manusia mempunyai postur tubuh yang tegak dan anggota badan yang berfungsi ganda. Dari segi rohani manusia mempunyai akal untuk berpikir sekaligus nafsu untuk merasa. Akal mampu membedakan yang baik dan yang buruk, dengan akal pikiran manusia juga dapat

${ }^{1}$ Dendy Sugono, Kamus Besar Bahasa Indonesia pusat Bahasa, (Jakarta: PT Gramedia Pustak Utama, edisi ke-4, 2008), 725.

${ }^{2}$ Soerjono, dkk., Al-Qur'an dan terjemahannya (Seamarang: Toha Putra, 1989), 13.

${ }^{3}$ Musa Asy'ari, Filsafat Islam Sunnah Nabi Dalam Berfikir (Yogyakarta: Lesfi, 1999), 214-215.

${ }^{4}$ Koentjaraningrat, Pengantar Ilmu Antropologi (Jakarta: Rineka Cipta, 1990), 61.

${ }^{5}$ Achmad Mubarok, Psikologi Dakwah, (Jakarta: Pustaka Firdaus, 2002), 1. 
mengembangkan dirinya kearah yang lebih positif, akal dan nafsu tidak bekerja secara terpisah, melainkan saling memberi pertimbangan. ${ }^{6}$

Manusia dalam pandangan Islam, selalu dikaitkan dengan suatu kisah tersendiri. Manusia tidak semata menggambarkan sebagai hewan tingkat tinggi yang berkuku pipih, berjalan dengan dua kaki dan pandai berbicara. Dalam Islam manusia lebih luhur dan ghaib.7 Banyak pendapat tokoh yang menuangkan pikirannya mengenai manusia, misalnya Omar Mohammad Al-Taumy Al-Syaibany yang mengatakan bahwa manusia adalah makhluk yang mulia, manusia juga merupakan makhluk yang mampu berpikir dan manusia merupakan makhluk tiga dimensi (yang terdiri dari badan, ruh dan kemampuan berpikir), manusia didalam proses tumbuh kembangnya dipengaruhi oleh dua faktor utama yaitu keturunan dan faktor lingkungan. ${ }^{8}$

Sedangkan Murtadha Muthahhari memandang manusia sebagai makhluk yang terdiri dari pada yang ada pada malaikat dan apa yang ada pada hewan.Dengan demikian dalam diri manusia terdapat unsur kehewanan yang meliputi nafsu,amarah dan lainnya dan terdapat unsur yang tidak dimiliki hewan seperti akal dan lainnya, jika melihat unsur tersebut sesungguhnya diciptakan untuk di uji, karena unsur-unsur tersebut yang mendorong lahirnya serangkaian potensi. Hal itulah yang menjadikan manusia sebagai makhluk yang unik dan mempunyai keunggulan melebihi makhluk lain. ${ }^{9}$ Murtadha Muthahhari juga mengatakan bahwa manusia adalah makhluk evolusi terahir. Murtadha Muthahhari tidak merasa puas dengan jawaban para filosof Barat yang mengatakan tentang manusia, apakah yang membedakan manusia dengan binatang atau hewan? Descrates sebagai kaum Rasionalis mengatakan bahwa yang membedakan manusia dengan hewan adalah pada tabiat rasional yang dimiliki oleh manusia, sedangkan kaum humanis mengatakan bahwa manusia adalah makhluk yang bertanggung jawab, maka dengan tanggung jawabnya yang membedakan manusia dengan makhluk lain. Dengan jawaban-jawaban yang telah dikemukakan oleh filosof Barat, Murtadha Muthahhari tidak merasa puas dengan jawaban tersebut, Murtadha Muthahhari membantah teori-teori yang telah dikemukakan oleh filosof Barat, dan menjawab pertanyaan tersebut dalam perspektif religius karena baginya merupakan suatu solusi yang tepat.

Adapun konsep manusia menurut al-Qur'an adalah sebagai berikut: Kata insan diambil dari akar kata uns yang berarti jinak, harmonis, dan tampak. Pendapat ini jika ditinjau dari sudut pandang al-Qur'an lebih tepat dari pada yang berpendapat bahwa ia diambil dari kata nasiya (lupa), atau nasa-yanusu (berguncang) dan mengandung arti "pergerakan atau dinamisme"10 Merujuk pada asal kata al-Insan dapat dipahami bahwa manusia pada dasarnya memiliki potensi yang positif untuk tumbuh serta berkembang secara fisik maupun mental spiritual. Di samping itu, manusia juga dibekali dengan

${ }^{6}$ Amin Syukur, Pengantar Studi Islam (Semarang: Bima Sejati, 2000), 1.

7 Murtadha Muthahhari, Perspektif Al-Quran Tentang Manusia dan Agama (Bandung: Mizan, 1998), 117.

${ }^{8}$ Adzkira Ibrahim, "Pengertian Manusia Menurut Para Ahli" diakses pada tanggal 17 Mei 2019.

${ }^{9}$ Hairus Saleh, filsafat Manusia Studi Komparatif antara Abdurrahman Wahid dan Murtadha, 48.

${ }^{10}$ Quraish Shihab, Wawasan Al-Qur'an: Tafsir Maudhu'i Atas Pelbagai Persoalan Umat (Bandung: Mizan Media Utama, 2001), 280. 
sejumlah potensi lain, yang berpeluang untuk mendorong ia ke arah tindakan, sikap, serta perilaku negatif dan merugikan. ${ }^{11}$

Kata basyar diambil dari akar kata yang mulanya berarti penampakan sesuatu dengan baik dan indah, dari akar yang sama lahir kata basyarah yang berarti kulit. Dari sisi lain diamati bahwa banyak ayat-ayat Al-Qur'an yang menggunakan kata basyar yang mengisyaratkan bahwa proses kejadian manusia sebagai basyar melalui tahap-tahap. Disini tampak bahwa kata basyar dikaitkan dengan kedewasaan dalam kehidupan manusia yang menjadikannya mampu memikul tanggung jawab, sebab itu pula tugas kekhalifahan dipikulkan kepada basyar seperti dijelaskan dalam Al-Qur'an surat Arruum ayat $20::^{12}$

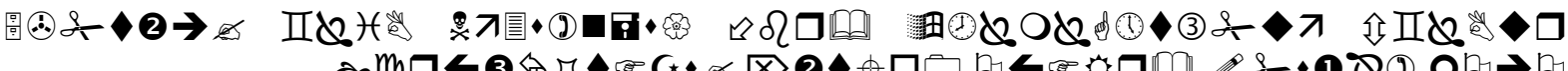

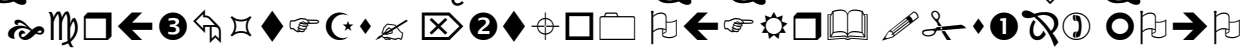

( الروم: 20/30)

Artinya: Dan di antara tanda-tanda kekuasaan-Nya ialah Dia menciptakan kamu dari tanah, kemudian tiba-tiba kamu (menjadi) manusia yang berkembang biak. (Q.S. Ar-Ruum [30] : 20)

Kata an-Naas dalam al-Qur'an umumnya dihubungkan dengan fungsi manusia sebagai makhluk sosial. Manusia diciptakan sebagai makhluk bermasyarakat, yang berawal dari pasangan laki-laki dan wanita kemudian berkembang menjadi suku dan bangsa untuk saling kenal mengenal "berinteraksi". Hal ini sejalan dengan teori "strukturalisme" Giddens yang mengatakan bahwa manusia merupakan individu yang mempunyai karakter serta prinsip berbeda antara yang lainnya tetapi manusia juga merupakan agen social yang mempengaruhi atau bahkan dibentuk oleh masyarakat dan kebudayaan dimana ia berada dalam konteks sosial. ${ }^{13}$

Manusia menurut Al-Qur'an, memiliki potensi untuk meraih ilmu dan mengembangkannya dengan seizin Allah. Karena itu bertebaran ayat yang memerintahkan manusia menempuh berbagai cara untuk mewujudkan hal tersebut. Allah juga menegaskan bahwa pengetahuan manusia amatlah terbatas. Allah berfirman: 14

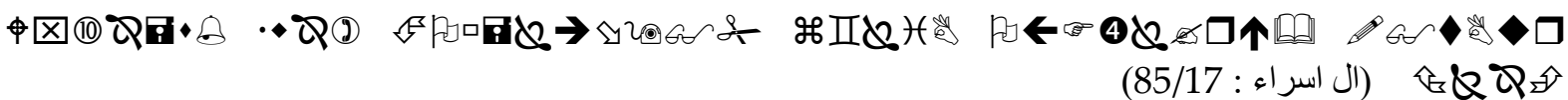

Artinya: "Kamu hanya di beri pengetahuan yang sedikit". (Q.S. Al-Israa' [17] :85)

Kepribadian secara utuh hanya mungkin dibentuk melalui pengaruh lingkungan, khususnya pendidikan. Adapun sasaran yang dituju dalam pembentukan kepribadian ini adalah kepribadian yang memiliki akhlak yang mulia. Dan tingkat kemuliaan akhlak erat kaitannya dengan tingkat keimanan. Para penganut teori psikoanalisis menyebut manusia sebagai homo volens (makhluk berkeinginan). Menurut aliran ini, manusia adalah makhluk yang memiliki perilaku interaksi antara komponen biologis (id),

${ }^{11}$ Jalaludin, Teologi Pendidikan (Jakarta: PT Raja Grafindo Persada, 2001), 21.

${ }^{12}$ Quraish Shihab, Wawasan Al-Qur'an: Tafsir Maudhu'i Atas Pelbagai Persoalan Umat, 278-279.

${ }^{13}$ Najm El Habeb's, Kedudukan Manusia dalam Alam Semesta, (Kajian Filsafat Pendidikan), diakses pada tanggal 18 Mei 2019.

${ }^{14}$ Quraish Shihab, Wawasan Al-Qur'an. cet ke XI (Bandung: Mizan, 2000), 435-436. 
psikologis (ego), dan social (superego). Di dalam diri manusia tedapat unsur animal (hewani), rasional (akali), dan moral (nilai). Sementara para penganut teori behaviorisme menyebut manusia sebagai homo mehanibcus (manusia mesin). Behavior lahir sebagai reaksi terhadap introspeksionisme (aliran yang menganalisa jiwa manusia berdasarkan laporan subjektif dan psikoanalisis (aliran yang berbicara tentang alam bawa sadar yang tidak nampak). Behavior yang menganalisis perilaku yang nampak saja. Menurut aliran ini segala tingkah laku manusia terbentuk sebagai hasil proses pembelajaran terhadap lingkungannya, tidak disebabkan aspek.

Para penganut teori kognitif menyebut manusia sebagai homo sapiens (manusia berpikir). Menurut aliran ini manusia tidak di pandang lagi sebagai makhluk yang bereaksi secara pasif pada lingkungannya, makhluk yang selalu berfikir. Penganut teori kognitif mengecam pendapat yang cenderung menganggap pikiran itu tidak nyata karena tampak tidak mempengaruhi peristiwa. Padahal berpikir, memutuskan, menyatakan, memahami, dan sebagainya adalah fakta kehidupan manusia.

Sebenarnya manusia itu terdiri dari 3 unsur yaitu: 1) Jasmani: terdiri dari air, kapur, angin, api dan tanah; 2) Ruh: terbuat dari cahaya (nur). Fungsinya hanya untuk menghidupkan jasmani saja; 3) Jiwa: manusia memiliki fitrah dalam arti potensi yaitu kelengkapan yang diberikan pada saat dilahirkan ke dunia. Potensi yang dimiliki manusia dapat di kelompokkan pada dua hal yaitu potensi fisik dan potensi rohania. Ibnu sina yang terkenal dengan filsafat jiwanya menjelaskan bahwa manusia adalah makhluk social dan sekaligus makhluk ekonomi. Manusia adalah makhluk social untuk menyempurnakan jiwa manusia demi kebaikan hidupnya, karena manusia tidak hidup dengan baik tanpa ada orang lain. Dengan kata lain manusia baru bisa mencapai kepuasan dan memenuhi segala kepuasannya bila hidup berkumpul bersama manusia.

Menurut al-Qur'an (Nabi Adam a.s), saat Allah Swt merencanakan penciptaan manusia, ketika Allah mulai membuat "cerita" tentang asal-usul manusia, Malaikat Jibril seolah khawatir karena takut manusia akan berbuat kerusakan di muka bumi. Di dalam Al-Quran, kejadian itu diabadikan. Allah Swt berfirman dalam Surat al-Hijr ayat 28-29:

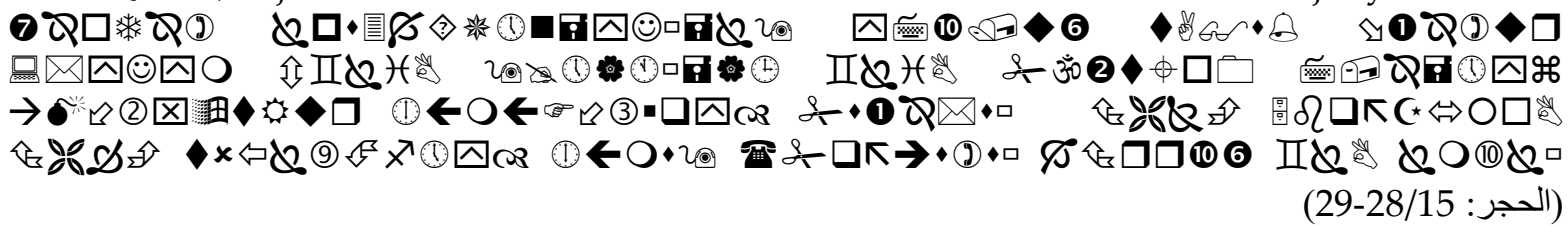

Artinya: "Dan (ingatlah), ketika Tuhanmu berfirman kepada Para Malaikat: "Sesungguhnya aku akan menciptakan seorang manusia dari tanah liat kering (yang berasal) dari lumpur hitam yang diberi bentuk. Maka apabila aku telah menyempurnakan kejadiannya, dan telah meniup kan kedalamnya ruh (ciptaan)-Ku, Maka tunduklah kamu kepadanya dengan bersujud". (Q.S. Al-Hijr [15]: 28-29)

Firman inilah yang membuat malaikat bersujud kepada manusia, sementara iblis tetap dalam kesombongannya dengan tidak melaksanakan firman Allah. Inilah dosa yang pertama kali dilakukan oleh makhluk Allah yaitu kesombongan. Karena kesombongan tersebut Iblis menjadi makhluk paling celaka dan sudah dipastikan masuk neraka. Kemudian Allah menciptakan Hawa sebagai teman hidup Adam. Allah berpesan pada Adam dan Hawa untuk tidak mendekati salah satu buah di surga, namun Iblis menggoda mereka sehingga terjebaklah Adam dan Hawa dalam kondisi yang 
menakutkan. Allah menghukum Adam dan Hawa sehingga diturunkan kebumi dan pada akhirnya Adam dan Hawa bertaubat. Taubat mereka diterima oleh Allah, namun Adam dan Hawa menetap dibumi.

Adam adalah ciptaan Allah yang memiliki akal sehingga memiliki kecerdasan, bisa menerima ilmu pengetahuan dan bisa mengatur kehidupan sendiri. Inilah keunikan manusia yang Allah ciptakan untuk menjadi penguasa didunia, untuk menghuni dan memelihara bumi yang Allah ciptakan. Dari Adam inilah cikal bakal manusia diseluruh permukaan bumi. Melalui pernikahannya dengan Hawa, Adam melahirkan keturunan yang menyebar ke berbagai benua diseluruh penjuru bumi; menempati lembah, gunung, gurun pasir dan wilayah lainnya diseluruh penjuru bumi. Hal ini dijelaskan dalam AlQur'an Surat Al-Isra' ayat 70 yang berbunyi:

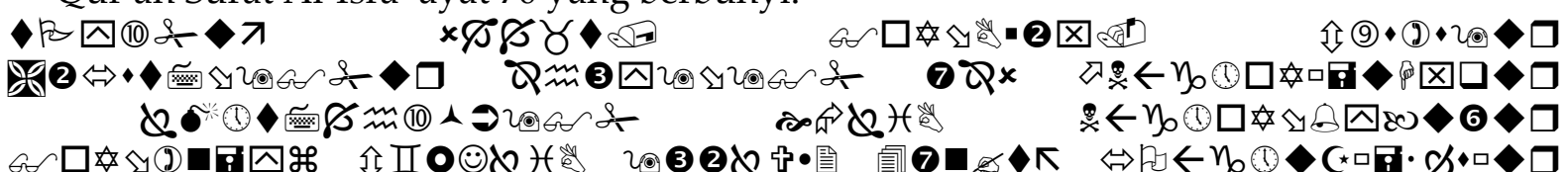
(ال اسراء:

Artinya: "Dan Sesungguhnya telah Kami muliakan anak-anak Adam, Kami angkut mereka di daratan dan di lautan, Kami beri mereka rezki dari yang baik-baik dan Kami lebihkan mereka dengan kelebihan yang sempurna atas kebanyakan makhluk yang telah Kami ciptakan". (Q.S. Al-Isra' [17]: 70)

Sejak manusia menuntut kemajuan dan kehidupan, maka sejak itu timbul gagasan untuk melakukan pengalihan, pelestarian dan pengembangan kebudayaan melalui pendidikan. Untuk itu dalam sejarah pertumbuhan masyarakat, pendidikan senantiasa menjadi perhatian utama dalam rangka memajukan kehidupan generasi demi generasi sejalan dengan tuntutan kemajuan masyarakat. Dalam perkembangan dunia pendidikan, berbagai teori dikembangkan para tokoh pendidikan. Perkembangan tersebut telah memberi warna yang beragam terhadap pola pendidikan. Teori pendidikan empirisme, nativisme, dan konvergensi menjadi rujukan dan sumbangsih yang mempengaruhi dalam perkembangan dunia pendidikan.

Sebagai sumber pendidikan, al-Qur'an memilik prinsip-prinsip yang menjadi acuan untuk menghasilkan teori dalam pendidikan. Prinsip tersebut adalah tauhid dan risalah ilahiyah. Prinsip tauhid menjadi landasan utama karena didalamnya memberikan pemahaman tentang keesaan Allah dan eksistensi manusia dengan perintah-Nya. Sedangkan risalah ilahiyah merupakan pesan-pesan Allah yang disampaikan kepada manusia melalui rasul mengandung unsur-unsur pendidikan. Teori-teori pendidikan dalam al-Qur'an dapat dipelajari melalui ayat-ayat al-Qur'an yang menjadi rujukan, dalam kandungan ayat al-Qur'an tersebut Allah swt telah memberikan panca indra sebagai modal utama. Sedangkan dalam hadits, teori pendidikan yang dikembangkan melalui fitrah (potensi) manusia.

Teori pendidikan merupakan landasan dan pijakan awal dalam pengembangan praktik pendidikan, misalnya pengembangan kurikulum, manajemen sekolah dan proses belajar-mengajar. Kurikulum dan pembelajaran memiliki keterkaitan dengan teori pendidikan atau dalam penysusunan suatu kurikulum dan rencana pembelajaran ini mengacu pada teori pendidikan.

Berbagai teori yang dikembangkan saat ini telah mewarnai proses dan praktik pendidikan. Sumbangsih para tokoh dalam menciptakan teori telah memberikan 
perkembangan dan kemajuan dalam proses pendidikan. Lahirnya teori dalam bidang pendidikan memberikan warna baru terhadap sistem pendidikan, proses belajar mengajar, manajemen sekolah dan metode pembelajaran. Adanya pergeseran metode dan pola didik pengajar terhadap peserta didik merupakan proses dari pelaksanaan teori dalam bidang pendidikan. Sebagai contoh berkembangnya pola pendidikan active learning dimana proses pembelajaran tidak hanya terpusat pada pengajar akan tetapi peserta didik mempunyai peranan sangat menentukan hasil belajar. Hal ini dipelopori oleh teori yang berkembang yaitu teori behaviorisme dimana setiap manusia mempunyai kemampuan untuk berpikir dan melakukan setiap aktifitas dalam proses belajar. Sehingga dengan teori ini setiap peserta didik diberikan ruang kebebasan untuk melakukan kegiatan yang disesuaikan dengan kemampuan peserta didik, tugas pengajar bersifat pengarah dan fasilitator, hal ini memungkinkan terbentuknya rasa percaya diri serta kemampuan peserta didik untuk menciptakan hal-hal yang inovatif dan kreatif.

Teori pendidikan yang dikembangkan dunia Barat telah memberikan sumbangsih pada perkembangan ilmu pengetahuan di dunia, dalam berbagai praktek pola pendidkian yang bersumber dari Barat berorientasi pada sudut material dan menghasilkan keuntungan kepada manusia secara materi. Karena bersandar pada materi maka sesuatu yang tidak empiris dianggap mitos. Hal ini menyebabkan pola pikir manusia cenderung matrealistis, logis dan hanya berorientasi kepada akal.

Di sisi lain yang sangat penting yang tidak tersentuh oleh pendidikan Barat adalah qalbu atau hati. Sehingga memungkinkan terjadinya kemampuan secara kognitif akan tetapi secara moral dan spiritual mengalami kekosongan. Ini dapat menimbulkan peluang sikap agresif, ambisius, dan persaingan antar sesama manusia sehingga menimbulkan kekerasan antar individu, golongan dan negara serta terjadi kehancuran terhadap dunia.

Selain itu, pola pendidikan barat telah mewariskan dikotonomi pendidikan umum dan agama hal ini terjadi dalam praktek pendidikan Islam. Akan tetapi Al-Qur'an dalam berbagai keterangan ayat menjelaskan bahwa tujuan kehidupan di dunia adalah kebahagiaan dunia dan akhirat dan landasan pendidikan dalam tauhid ilahi yaitu semua berpusat pada Allah Swt. ${ }^{15}$ Pendidikan Islam dapat ditinjau dari berbagai aspek. Aspek sejarah, pemikiran, lembaga, filsafat, dan lain sebagainya. Pendidikan Islam sebagai suatu kajian telah semakin berkembang, cakupannya semakin meluas sehingga tidak hanya sebagai proses belajar mengajar atau sebagai kajian kelembagaan saja.

Salah satu diantara aspek kajian pendidikan Islam tersebut yakni filsafat. Filsafat sebagai kajian yang mengedepankan esensi atau hakikat adalah salah satu bagian yang penting untuk dibahas dalam pendidikan Islam. Apa sebab? Karena pada dasarnya tidak ada aspek kehidupan manusia yang tidak terkait dengan filsafat, termasuk pendidikan Islam. Dalam dunia pendidikan Islam banyak hal yang harus disorot dari sudut pandang filsafat.

Ketika berbicara tentang pendidikan, maka berbagai aspek terkait dengan pendidikan tersebut dikaji dari sudut esensinya (hakikatnya). Pendidikan terkait dengan manusia, karena manusialah yang akan dijadikan objek pendidikan di samping berfungsi sebagai subjek pendidikan. Kajian tentang hakikat manusia perlu dilaksananakan, mengenal hakikat manusia, kaitannya dengan pendidikan, apakah manusia perlu dididik

${ }^{15}$ https://jurnal.staialhidayahbogor.ac.id. Diakses pada tanggal 6 mei 2019. 
atau tidak perlu dididik, kalau perlu dididik bagaimana cara-cara mendidiknya, dan berbagai pembahasan lainnya.

Karena pendidikan itu terkait tentang apa kegunannya, maka perlukah mengkaji serta membahas secara mendalam tentang maksud dan tujuan pendidikan. Merumuskan tujuan pendidikan, bukanlah mudah, harus dilaksanakan dengan pemikiran yang mendalam serta komprehensif, untuk itu diperlukan berpikir filosofis. Di dalam proses pendidikan perlu ada bahan yang disajikan, apa yang harus diberikan oleh pendidik kepada peserta didik. Bukan hal yang mudah pula untuk menampilkan apa materi (bahan) atau kajian yang pantas dan patut sesuai pula dengan tujuan pendidikan, sebab itu perlu disusun kurikulum. Penyusunan kurikulum tentu memerlukan pemikiran yang mendalam pula sehingga bahan kajian itu tepat pada sasarannya, berkaitan pula dengan squence dan content kurikulum. Pembahasan ini semua memerlukan pula pemikiran filosofis.

Pengkajian terhadap komponen pendidik dan peserta didik, juga bagian yang memerlukan pemikiran filsafat. Siapakah yang layak dijadikan dan disebut pendidik, kriteria dan penyusunan apa yang dibutuhkan untuk itu serta tugas apa yang diembannya. Begitu juga kajian tentang peserta didik, kemana peserta didik mau dibawa, siapa sebetulnya yang dikategorikan peserta didik. Dan berbagai persoalan lainnya mengenai pendidik dan peserta didik juga memerlukan pemikiran dan pembahasan yang mendalam. Metode dan evaluasi pendidikan juga memerlukan pemikiran filosofis agar tepat sasaran dalam menggunakannya.

Salah satu yang mendasar dari tujuan pendidikan dalam Islam yakni terbentuknya pribadi Muslim seutuhnya. Hal ini juga bukanlah sesuatu perbincangan yang mudah, dimulai dari pertanyaan apa kepribadian Muslim tersebut sampai pada bagaimana upaya mewujudkannya. Tentu menjawab hal ini tidak bisa dilepaskan dari pemikiran filosofis. Dengan demikian kajian filsafat pendidikan merupakan suatu kajian yang dibutuhkan guna mengetahui hakikat pendidikan Islam.

Filsafat pendidikan Islam adalah bagian dari filsafat pendidikan yang ditinjau dari sudut pandang Islam. Sutan Zanti Arbi mengemukakan dalam bukunya Filsafat Pendidikan, bahwa filsafat biasanya tidak menarik bagi orang kebanyakan dan bahkan pada mahasiswa umumnya tidak begitu berminat untuk mengkajinya. Mereka beranggapan, bahwa filsafat itu adalah berkenaan dengan persoalan yang abstrak bahkan misterius, yang jauh terpisah dari kehidupan sehari-sehari. Akan tetapi, apabila kita membahas filsafat, dan khusunya filsafat pendidikan, maka kita akan mendapatkan bahwa mengkaji filsafat sebenernya tidaklah begitu sukar untuk memahami cukup banyak daripadanya. Lagi pula, kita akan menemukan bahwa antara hal-hal yang dibahas dalam filsafat pendidikan itu terdapat juga yang sudah kita pikirkan atau kita bicarakan sehari-hari. Kendatipun tidak secara begitu sistematis atau mendalam dan tuntas. Kemudian kita akan melihat, bahwa apa yang terdapat dalam filsafat pendidikan itu masuk akal, serta berguna atau dapat berguna bagi mereka yang ingin lebih memahami atau yang ingin melaksanakan kegiatan pendidikan secara lebih mantap dan bermakna.

Apa yang diungkapkan terdahulu memberi pengertian kepada kita bahwa sesungguhnya filsafat pendidikan khususnya filsafat pendidikan Islam sangat berguna dan bermanfaat bagi siapa saja yang terlibat dalam dunia pendidikan Islam, termasuk para guru. Sebab dengan berbekal pengetahuan filsafat pendidikan akan dapat 
digunakan untuk memecahkan permasalah pendidikan. Permasalah pendidikan yang bersifat filosofis tentu diberi jawaban bersifat filosofis pula, seperti berbagai permasalahan yang telah disebutkan di atas, diantaranya tentang tujuan pendidikan, kurikulum pendidikan, pendidik dan peserta didik, metode dan evaluasi pendidikan, dan aspek pendidikan yang memerlukan pembahasan secara filosofis.

Tujuan pendidikan Islam Murtadha Muthahhari terdapat pada tujuan pendidikam Islam yang universal. Yang mana didalam bukunya Murthadha Muthahhari, Manusia Sempurna, menjelaskan "Pengenalan manusia sempurna ini tidak hanya berguna secara teoritis. Pengetahuan ini juga harus kita gunakan untuk mengikuti jalan Islam guna menjadi Muslim yang sebenarnya dan menjadikan masyarakat sungguh-sungguh Islami. Dengan begitu, jalan tersebut menjadi terang dan hasilnya jelas.

Pendidikan juga pembangunan sosok makhluk hidup yang yang mewadahi serta memfasilitasi perkembangan potensi-potensi mereka. Berkaitan dengan pendidikan manusia, disana terdapat kekhususan-kekhususan. Sebagai contoh, kita tidak dapat mengembangkan potensi-potensi tertentu pada tumbuhan, sebagaimana juga tidak dapat membekukan potensi-potensi yang sudah menjadi keharusannya. Namun pada manusia, yang demikian dapat terjadi, dimana sebagian potensinya berkembang sementara sebagian lagi potensinya membeku. Dan inilah yang menjadi sabab terjadinya ketidak seimbangan pada diri manusia. Oleh karena itu, dalam pendidikan manusia sangat diperlukan pengembangan seluruh potensi-potensinya secara seimbang. ${ }^{16}$

Al-Qur'an benar-benar telah tampil sebagai "Kitab Pendidikan". Al-Qur'an selain berisi ajaran-ajaran tentang pendidikan terutama dalam bidang akhlak, juga telah memberiisyarat dan inspirasi bagi lahirnya konsep pendidikan. Namun demikian sungguh kita dapat mengemukakan argumentasi secara meyakinkan bahwa Al-Qur'an sebagai "Kitab Pendidikan Islam", kita tidak dapat mengatakan bahwa antara Al-Qur'an dan kitab pendidikan itu sama keduanya tetap berbeda. Al-Qur'an berasal dari Allah, bersifat mutlak, berlaku sepanjang zaman dan pasti benar. Sedangkan kitab pendidikan berasal dari hasil ijtihad manusia, memiliki kebatasan, dapat berubah setiap zaman, dan dapat mendukung kesalahan. Kitab pendidikan, yakni Kitab Pendidikan Islam adalah hasil ijtihad manusia yang berdasarkan al-Qur'an. ${ }^{17}$

Al-Qur'an telah memberi isyarat bahwa permasalahan pendidikan sangat penting. Jika Al-Qur'an dikaji lebih mendalam maka akan di temukan beberapa prinsip dasar pendidikan, yang selanjutnya bisa dijadikan inspirasi untuk dikembangkan dalam rangka membangun pendidikan yang bermutu. Ada beberapa indikasi yang terdapat dalam Al-Qur'an yang berkaitan dengan pendidikan antara lain: menghormati akal manusia, bimbingan ilmiah, fitrah manusia, penggunaan cerita (kisah) untuk tujuan pendidikan dan memelihara keperluan sosial masyarakat.

Dengan pengetahuan dan pendidikan, manusia menjadi manusia yang berkebudayaan dan berperadaban. Dengan kegiatan pendidikan dan pembelajaran, manusia mendapatkan ilmu pengetahuan yang serat dengan nilai kebenaran baik yang universal, abstrak, teoritis, maupun praktis. Nilai kebenaran ini selanjutnya mendorong terbentuknya sikap dan perilaku yang arif dan berkeadilan. Sikap yang demikian itu selanjutnya menjadi modal bagi manusia untuk membangun kebudayaan dan

${ }^{16}$ Murtadha Mutahhari, Dasar-dasar Epistemologi Pedidikan Islam, (Jakarta: Sadra Internasional Instutie, 2011), h .51-52.

${ }^{17}$ Abuddin Nata, Pendidikan dalam Perspektif Al-Qur'an (Jakarta: Buku Daras, 2005), 4-5. 
peradaban. Kebudayaan baik yang bersifat material maupun yang bersifat spiritual, adalah upaya manusia untuk mengubah dan membangun hubungan berimbang baik secara horizontal,maupun vertical. ${ }^{18}$

Pada dimensi dialektika horizontal, pendidikan Islam hendaknya mampu mengembangkan realitas kehidupan, baik yang menyangkut dengan dirinya, masyarakat, maupun alam semesta berserta segala isinya. Sementara dalam dimensi ketundudkan vertikal mengisyaratkan bahwa, pendidikan Islam selain sebagai alat untuk memelihara, memanfaatkan, dan melestarikan sumber daya alam,juga hendaknya menjadi jembatan untuk memahami fenomena dan misteri kehidupan dalam upayanya mencapai hubungan yang abadi dengan Khaliqnya. ${ }^{19}$

Murtadha Muthahhari adalah seorang tokoh intelektual Iran yang terkenal sangat produktif dalam mengeluarkan pemikiran-pemikiran baru mengenai ajaran Islam lewat karya-karyanya. Bisa dikatakan, bahwa beliau adalah kampiun bagi kebangkitan tradisi intelektual dan rasional di dunia Muslim. Namun, di sisi lain, belum di jumpai sebuah karya khusus dari beliau mengenai pendidikan.

Murtadha Muthahhari adalah seorang ulama dan filosof terkemuka Islam kontemporer. Ia lahir pada 2 Februari 1919 di Farhiman, berkebangsaan Irak dan ia mampu memadukan dua sisi pemikiran Islam yang sering dianggap paling bertentangan, yaitu tradisionalisme dan rasionalisme. Ia juga salah satu pendiri organisasi Jam'iyat-e Ruhaniyyat-e Mubariz (Himpunan Ulama Pejuang). Dan salah seorang arsitek revolusi Islam yang akhir hayatnya mati syahid ditembak oleh kelompok yang menanamkan diri Furqon pada 1 Mei 1979. Karena kelompok ini tidak menyukai berkuasanya para ulama dalam pemerintahan revolusi Islam. ${ }^{20}$

Iman dan ilmu adalah karakteristik kemanusiaan, maka pemisahan keduanya akan menurunkan martabat manusia. Iman tanpa ilmu akan mengakibatkan fanatisme dan kemunduran, takhayul dan kebodohan. Ilmu tanpa iman akan digunakan untuk memuaskan kerakusan, kepongahan, ambisi, penindasan, perbudakan, penipuan dan kecurangan. Muthahhari menegaskan bahwa Islamlah satu-satunya agama yang memadukan iman dan ilmu (sains). ${ }^{21}$

Keterkaitan antara iman dan ilmu serta pertalian keduanya yang tidak dapat dipisahkan selalu mewarnai pemikiran dan dasar tujuan pendidikan Muthahhari. Lazimnya para ulama yang lain, Muthahhari menegaskan bahwa kewajiban menuntut ilmu tidak bisa tergantikan. Banyak sekali hadis-hadis yang mewajibkan menuntut ilmu. Mencari ilmu wajib hukumnya bagi setiap muslim. Arti wajib hukumnya dari hadis ini adalah bahwa salah satu kewajiban Islam, yang sejajar dengan semua kewajiban lainnya adalah mencari dan menuntut ilmu. Mencari ilmu adalah wajib hukumnya bagi setiap orang muslim; tidak hanya dikhususkan bagi satu kelompok dan tidak bagi kelompok yang lain.

Di dalam sejarah disebutkan bahwa pada masa sebelum datangnya Islam, sebagian masyarakat berperadaban pada waktu itu memandang bahwa mencari ilmu adalah hak sebagian kelompok, dan tidak mengakui bahwa mencari ilmu adalah hak seluruh lapisan

18 Abuddin Nata, Filsafat Pendidikan (Jakarta: 2011), 54.

${ }^{19}$ Al-Rasyidin, Samsul Nizar, Filsafat Pendidikan Islam (Jakarta: Ciputat Press, 2005), 37.

20 Hidayatullah, Pemikiran Teologis Murtadha Muthahhari Tentang Keadilan Tuhan (Bandar Lampung: Perpustakaan Ushuluddin UIN RIL, 1999), 2-3.

${ }^{21}$ Murtadha Muthahhari, Man and Universe (Qum: Ansariyan Publication, $\left.1401 \mathrm{H}\right), 11$. 
masyarakat. Di dalam Islam, ilmu bukan hanya dianggap sebagai hak setiap orang, melainkan Islam menganggapnya sebagai tugas dan kewajiban bagi semua orang. Mencari ilmu adalah sebuah kewajiban sebagaimana kewajiban-kewajiban yang lain seperti sholat, puasa, zakat, dan haji.

Islam pada abad keemasan bagaikan harta karun kekayaan peradaban intelektual yang tak ternilai harganya, menyebar hampir seluruh dunia. Kehebatan imperium Islam dalam abad keemasan tersebut melampaui kehebatan imperium Romawi \& abad sebelumnya. Diantara nilai peradaban intelektualnya yaitu:22 Pertama, Semangat mencari ilmu yang luar biasa dari orang-orang Islam. Hal ini bisa terjadi karena dipicu oleh doktrin Islam, bahwa mencari ilmu, mengembangkan dan kemudian mengamalkannya untuk membangun kehidupan, adalah wajib hukumnya. Semangat pencarian ilmu tersebut menjadi kunci penjelajahan intelektual Islam pada puncaknya abad ke-9, 10 dan $11 \mathrm{M}$; Kedua, semangat pencarian ilmu tersebut menemukan momentumnya dalam imperium Islam dibawah bimbingan para khalifah. Pada masa itu dana serta fasilitas dari istana untuk mempercepat peradaban baru yang berbasis pengetahuan (knowledge based) merupakan kebijakan prioritas.

Menuntut ilmu juga tidak memiliki batasan waktu atau masa tertentu, sebagaimana hadis Nabi saw, "Carilah Ilmu dari buaian sampai ke liang kubur" (Bukhari \& Muslim). Pada setiap zaman manusia haruslah menggunakan kesempatan yang ada untuk mencari ilmu. Keluasan kewajiban menuntut ilmu juga digambarkan dalam hadis, "Carilah ilmu walaupun di negeri Cina". Artinya bahwa mencari ilmu tidak memiliki batasan tempat tertentu. Dalam hal ini dapat dilihat bahwa Islam telah memerintahkan menuntut ilmu dengan tiada batasan golongan tertentu, waktu, tempat dan pengajarnya tetapi mengapa Islam begitu mundur dan generasi muda saat ini selalu berteman dengan kebodohan? Hal inilah yang sangat menyedihkan karena sesungguhnya perintah-perintah yang mulia ini telah ditinggalkan begitu saja oleh generasi muda saat ini.

Dalam mengambil ilmu sebagai hikmah Muthahhari juga tidak membatasi pada satu golongan tertentu. Hal ini berdasarkan hadis Rasulullah saw, "Hikmah adalah barang orang mukmin yang hilang, yang akan diambil di mana saja mereka menemukannya". Dalam Nahjul Balaghah,Imam Ali sebagaimana dikutip Murtadha Muthahhari.“Hikmah adalah barang orang mukmin yang hilang, maka ambillah hikmah itu meskipun dari orang munafik". ${ }^{23}$ Dilihat dari perspektif pendidikan dan pengajaran, ketentuan-ketentuan akhlak Islamditujukan untuk mendidik manusia agar sesuai dan selaras dengan apa yang diinginkan oleh Islam. Sasaran utama pendidikan dipandang dari sisi sebuah kerangka pengantar terbentuknya masyarakat yang baik, maka pembentukan kepribadian seseorang sangatlah penting. Islam sangat menjaga dan menghormati kesejatian Individu dan masyarakat. ${ }^{24}$ Al-Attas misalnya, menghendaki tujuan pendidikan Islam yaitu manusia yang baik, sedangkan Athiyah al-Abrasyi mengehendaki tujuan akhir pendidikan Islam yaitu manusia yang berakhlak mulia, ${ }^{25}$

${ }^{22}$ Mastuhu, Sistem Pendidikan Nasional Visioner Cet. ke-1 (Jakarta: Lentera Hati, 2007), 71-72.

${ }^{23}$ Murtadha Muthahhari, Ceramah-ceramah Seputar Persoalan Penting Agama dan Kehidupan cet. ke-1 (Jakarta: Lentera, 1999), 158.

${ }_{24}$ Murtadha Mutahhari, Dasar-dasar Epistemologi Pedidikan Islam. cet ke-1 (Jakarta: Sadra International Institute, 2011), 2.

${ }^{25}$ Muhammad Athiyah al-Abrasy, Dasar-dasar Pokok Pendidikan Islam. (terj). Bustami A. Gani dan Djohar Bahry (Jakarta: Bulan bintang, 1974), 15. 
Munir Mursih menghendaki tujuan pendidikan Islam yaitu manusia sempurna, ${ }^{26} \mathrm{Ahmad}$ D Marimba berpendapat bahwa tujuan pendidikan Islam adalah terbentuknya orang yang berkepribadian muslim. ${ }^{27}$

Pendidikan manusiawi dalam pandangan Murtadha Muthahhari dalam konteks pendidikan kritis adalah pendidikan yang mengembangkan potensi berpikir kreatif pada diri peserta didik serta membekali mereka dengan semangat kemerdekaan dalam proses pengembangan potensi berpikir. Tujuan pendidikan menurut Muthahhari adalah menumbuhkan kemampuan berpikir kritis dan memiliki karakteristik mampu berssosialisasi melalui metode tidak terbatas pada aksi dan refleksi semata tetapi mencakup muhasabah, muraqabah dan amal (humanisme dan pembebasan dalam pendidikan)." 28

\section{B. METODE PENELITIAN}

Jenis penelitian yang digunakan dalam penyusunan skripsi ini adalah penelitian perpustakaan (library research), dimaksud untuk mendapatkan informasi secara lengkap dan menetukan tindakan yang akan diambil dalam kegiatan ilmiah. ${ }^{29}$ Dalam penelitian ini data diolah dan digali dari berbagai buku yang memiliki keterkaitan dengan penelitian ini.

Adapun penelitian ini menggunakan metode deskriptif analisis, yaitu memaparkan secara mendalam dengan apa adanya secara obyektif sesuai dengan data yang dikumpulkan. Dan penelitian terdahulu yang relevan yang sudah dilakukan orang lain.

Penelitian ini bersifat filosofis yaitu penelitian yang memaparkan dan melaporkan suatu keadaan, objek tertentu kemudian dianalisis secara lebih kritis.

\section{HASIL DAN PEMBAHASAN}

\section{Implementasi Konsep Manusia dalam Pendidikan Islam}

Dikatakan oleh Fuad Hasan sebagaimana dikutip oleh Suharsono, Bahwa: “Tujuan pendidikan bukanlah sekedar membuat seseorang mampu dan mahir dalam ilmu pengetahuan dan teknologi atau terampil dan tangkas dalamsuatu kejuruan dan keahlian. Lebih dari sekedar penguasaan ilmu (science) yang bisa menunjang prestasi manusia, pendidikan seharusnyapun meliputi usaha demi terbentuknya fungsi nurani (conscience) sebagai pengatur akhlak dan adab". ${ }^{30}$

Tugas membangun manusia yang beramal dan berakhlak serta beradab itu diliput oleh ikhtar pendidikan. Pendidikan yang bertujuan membangun seutuhnya, sebagai pribadi yang mandiri dan sekaligus sebagai anggota masyarakat yang bermartabat. Pada hakekatnya pendidikan Islam mementingkan seluruh aspek tersebut dan ingin mewujudkan segala macam pendidikan secara utuh, karena pendidikan Islam adalah pendidikan manusia seutuhnya. Yaitu akal dan hatinya, rohani dan jasmaninya serta akhlak dan keterampilannya.

26 Muhammad Munir Mursi, at-Tarbiyah al-Islamiyah Usuluha wa Tatawwuruha fi Bilad alArabiyah, (Qahhirah: Alam al-Kutub, 1997), 18.

27 Ahmad D Marimba, Pengantar Filsafat Pendidikan Islam (Bandung: Al-Ma'rif, 1989), 39.

${ }^{28}$ Nurul Zainab, Paradigma Pendidikan Kritis, (Studi Komparasi Pemikiran Paulo Freire dan Murtadha Muthahhari)

29P Joko Subagyo, Metodologi Penelitian Teori dan Praktek, (Jakarta: Rhineka Cipta, 1991), h. 109.

30 Suharsono, melejitkan IQ, IE, dan IS (Jakarta: Inisiasi Press, 2002), 54. 
Pendidikan itu merupakan pembentukan perilaku (tasyri al-sajiyyah), karena sesungguhnya jiwa manusia sebagai makhluk yang berasal (diciptakan) dari materi yang kenyal dan dapat dibentuk. Karena itu manusia sewaktu kecilnya ibarat tanah kenyal yang lunak sehingga dapat dibentuk hingga akhirnya bersifat permanen. Ketika sudah permanen, tanah yang sudah keras dan mengering menjadi sukar untuk dibentuk, begitu pula manusia jika sudah dewasa.

Pendidikan dalam wujudnya selalu bertujuan membina kepribadian manusia, baik berupa ultimate-goal maupun bagi tujuan-tujuan dekat. Tujuan akhir pendidikan ialah kesempurnaan pribadi. Prinsip ini berpangkal pada asa self-realisasi, yakni merealisasi potensi-potensi yang sudah ada didalam martabat kemanusiaannya. Potensi-potensi itu baik berupa potensi-potensi intelektual, mental, rasa, karsa, maupun kesadaran moral, bahkan juga aspek-aspek keterampilan fisik dan perkembangan jasmani.

Pendidikan yang terutama dianggap sebagai proses pengoperan kebudayaan, pengembangan ilmu pengetahuan berarti membina pribadi manusia untuk mengerti, berpengetahuan atau tahu adalah asa utama untuk kebaikan, menuju kesempurnaan. Pandangan demikian telah ditanamkan oleh Socrates, dimana beliau berpendapat bahwa pengetahuan adalah kebijakan: "in Socrates we find a nobleattempt to fuse epistemology and axiology in the principle that knowledge is the master key to virtue". "pada Socrates kita menemukan suatu usaha mulia yakni mensinthesakan ilmu dan nilai dalam prinsip bahwa ilmu adalah kunci kebajikan", sedangkan ilmu mungkin hanya kita miliki melalui pendidikan, baik belajar melaluisekolah formal maupun informal (dalam masyarakat, made-self). ${ }^{31}$

Essensi kepribadian manusia, yang tersimpul dalam aspek-aspek: individualitas sosialitas dan moralitas hanya mungkin menjadi realita (tingkah laku, sikap) melalui pendidikan yang diarahkan diri sendiri (self-respect, self-realince, self-confidence) rasa tanggung jawab, dan sebagainya juga akan tumbuh dalam kepribadian manusia melalui proses pendidikan. Jika pendidikan itu tidak lain dari yang telah diterangkan maka setiap pendidik atau yang ingin mendidik haruslah menentukan falsafah dan tujuan, membuat rencana yang menyusun kurikulum cara pelaksanaan dan alat-alat yang digunakan haruslah demikian, malah setiap yang terlibat dalam usaha ini mestilah mengetahui walaupun sekedar yangperlu tentang perwatakan insan. Ia harus menggariskan prinsip serta dasar yang perlu serapkan kepada manusia didiknya mengikuti dasar yang telah diyakini dan diimani sehingga selaras dengan watak manusia itu.

Hubungan manusia dengan pendidikan sangat erat karena mempunyai ikatan yang tidak dipisahkan antara satu dengan yang lainnya. Pendidikan merupakan salah satu kebutuhan pokok dalam kehidupan manusia yang berfikir bagaimana menjalani kehidupan dunia ini dalam rangka mempertahankan hidupnya. Melalui pendidikan pula perkembangan kepribadian manusia dapat diarahkan kepada yang lebih baik. Dan melalui pendidikan kemampuan tingkah laku manusia dapat didekati dan di analisis secara murni. Kemampuan seperti itulah yang tidak dimiliki oleh makhluk Tuhan yang lainnya. Manusia dapat tumbuh dan berkembang melalui pendidikan, karena manusia dapat tumbuh berkembang melalui suatu proses alami menuju kedewasaan baik itu bersifat jasmani maupun bersifatrohani.

31 Muhammad Noor Syam, Filsafat Kependidikan dan Dasar Filsafat Kependidikan Pancasila, (Surabaya:Usaha Nasional, 1986), 178. 
Dengan pendidikan manusia dapat berkembang kemanusiaannya, dimana pendidikan sebagai fungsi strategis yaitu untuk mengaktualisasikan sekaligus mengembangkan semua potensi kemanusiaannya, baik dalam kehidupan kodrat maupun sifat kodratnya. Manusia dikatakan manusia pendidikan karena manusia akan selalu belajar terus menerus dengan sesuatu yang baru. Oleh karena itu pendidikan dan prosesnya merupakan suatu proses kemanusiaan dan pemanusiaan.

Dan penyusun akan membagi hubungan konsep manusia dengan pendidikan, sebagai berikut:

Pertama, konsep manusia dan hubungannya dengan tujuan pendidikan, maksudnya adalah bahwa peran pendidikan dalam pembinaan kepribadian terutama tersimpul dalam usahanya merealisasi tujuan pendidikan. Tujuan pendidikan secara umum, terutama untuk membina kepribadian manusia yang sempurna. Pengertian dan kriteria sempurna itu ditentukan oleh dasar pandangan masing-masing pribadi, masyarakat, bangsa, pada suatu tempat dan waktu. Karena itulah penentuan tujuan pendidikan bersumber atau ditentukan oleh asas-asas pandanngan ontologis dan axiologis. Jadi penetapan itu berlatar belakang filosofis. Konsekuensinya, pastilah akan ada variasi interprestasi baik mengenai makna pengertian sempurna, maupun aspekaspek lain dari rumusan tujuan pendidikan.32 Menurut al-Syaibani bahwa tujuan pendidikan tertinggi pendidikan Islam adalah "Mempersiapkan kehidupan dunia dan akhirat". Sementara tujuan akhir yang akan dicapai adalah mengembangkan fitrahpeserta didik, baik ruh, pisik, kemauan dan akalnya secara dinamis, sehingga akan terbentuk pribadi yang utuh dan mendukung bagi pelaksanaan fungsinya sebagai khalifah fi al-ard. ${ }^{33}$ Pendekatan tujuan ini memiliki makna, bahwa upaya pendidikan Islam adalah pembinaan pribadi muslim sejati yang mengabdi dan merealisasikan "kehendak" Tuhan sesuai dengan syari'at Islam, serta mengisi tugas kehidupan akhirat sebagai tujuan utama pendidikannya. ${ }^{34}$

Redja Mudyahardjo sebagaimana dikutip oleh Dauz Biotekno, menguraikan tujuan pendidikan sebagai perpaduan tujuan-tujuan pendidikan yang bersifat pengembangan kemampuan-kemampuan pribadi secara optimal dengan tujuan-tujan sosial yang bersifat manusia seutuhnya yang dapat memainkan perannya sebagai warga dalam berbagai lingkungan persekutuan hidup dan kelompok sosial". ${ }^{35}$ Adapun tujuan pendidikan yang lain, maka definisi yang paling sederhana yaitu perubahan yang diinginkan yang diusahakan oleh proses pendidikan atau usaha pendidikan untuk mencapai tujuannya baik pada tingkah laku individu maupun pada kehidupan pribadi, kehidupan bermasyarakat dan pada alam sekitar individu hidup, atau proses pendidikan

${ }^{32}$ Omar Mohammad Al-Toumy Al-Syaibany, Falsafah Pendidikan Islam (Jakarta: Bulan Bintang), 177.

${ }^{33}$ Hasan Langgulung, Manusia \& Pendidikan; Suatu Analisa Psikologis, Filsafat, dan Pendidikan (Jakarta: PT. Pusaka Al HusnaBaru, 2004), 67.

${ }_{34}$ Al-Rasyidin, dan Samsul Nizar, Pendekatan Historis, Teoritis dan Praktis: Filsafat Pendidikan Islam, (Jakarta: PT Ciputat Press, 2005), 36.

35 Dauz Biotekhno, Hakekat Manusia Dengan Pendidikan, diakses pada tanggal 06 September 2019. 
itu sendiri maupun proses pengajaran sebagai suatu aktivitas yang asasi dan sebagai proporsi diantara profesi-profesi asasi di dalam bermasyarakat. ${ }^{36}$

Jalaluddin dalam bukunya berjudul Filsafat Pendidikan mengatakan tujuan pendidikan membentuk pendidikan yang bersifat individual sekurang-kurangnya selalu bermula pada suatu kehendak lalu berubah menjadi keinginan, lalu individu berhenti sebentar pada tahap ini untuk berpikir dan termenung sebelum melanjutkan pada pelaksanaan berikut-berikut. Menurut Murthadha Muthahhari tujuan pendidikan Islam itu pribadi yang sempurna, ${ }^{37}$ yang diperincikan kedalam dua dimensi yaitu jasmani dan rohani. Ini berarti pendidikan yang baik adalah, pendidikan yang tidak hanyamemenuhi kebutuhan jasmani seperti pendidikan bertujuan untuk mendapatkan pekerjaan yang layak, gaji yang besar namun, pendidikanpun harus memenuhi kebutuhan rohani seperti kebahagian dalam hidup karena dengan ilmunya ia bisa bersosialisasi dengan orang lain, bermanfaat bagilingkungan sekitar, dan yang paling utama adalah menjadi manusia beriman kepada tuhannya dan memiliki sikap rendah hati di hadapan makhlu-Nya.

Tujuan pendidikan yaitu untuk menumbuhkan pola kepribadian manusia yang bulat melalui latihan kejiwaan, kecerdasan otak, penalaran, perasaan dan indra. Pendidikan ini harus melayani pertumbuhan manusia dalam semua aspeknya, baik aspek spiritual, intelektual, imajinasi, jasmaniah, ilmiah, maupun bahasanya.

Sampai saat ini, isu pendidikan masihmendapat perhatian yang sangat besar dari masyarakat. Hal ini merupakan dampakdari keinginan seluruh masyarakat indonesia yangingin mewujudkan mutu pendidikan indonesia yang lebih baik. Pendidikan merupakan tujuan dari orang tua dan juga pendidik yang berhubungan dengan nilainilai hidup seperti kesusilaan, keagamaan dan lain-lain. Selain itu, anak-anak dan generasi penerus merupakan kunci utama dari tujuan pendidikan tersebut. Oleh karena itu, sebagai generasi penerus bangsa ini, para pendidik dan orang tua mempunyai peran yang sangat penting untuk mewujudkan pendidikan yang lebih berkualitas.

Kedua, konsep manusia dan hubungannya dengan Kurikulum. Islam menganjurkan pendidikan dan perhatian terhadap jasmani, namun islam menentang sikap berlebih-lebihan dalammemenuhi kebutuhan jasmani. Semua ini tidak lain karena Islam menginginkan, sekaligus mewajibkan manusia untuk berlaku menurut cara yang senantiasa dapat membuat tubuhnya sehat, tumbuh dengan sehat, tanpa suatu penyakit yang menggerogotinya. ${ }^{38}$ Menurut Hamka sebagaimana dikuti oleh Azyumardi Azra, "Jasad (jims), manusia merupakan tempat di mana jiwa (al-qalb) berada". Meskipun jiwa merupakan tujuan utama bagi manusia, namun tanpa jism, jiwa tidak akan berkembang secara sempurna. Melalui wasilah jism, jiwa manusia akan dapat memberikan makna tertentu. Untuk itu manusia hendaknya senantiasa memelihara jasad dengan sebaikbaiknya. Adadua cara yang bisa ditempuh manusia dalam memelihara tubuhnya yaitu: 1) Sederhana dalam makan dan minum. Dalam hal ini, tubuh jangan diberikan makanan dan minuman melainkan yang dibutuhkan untuk kelangsungan kehidupannya; 2) Mengetahui ilmu kesehatan. Memelihara kesahatan tubuh adalah penting. Jika tubuh

${ }^{36}$ Jalaluddin, Filsafat Pendidikan, Manusia Filsafat dan Pendidikan (Jakarta: Radar Jaya Offset, 2002), 121.

37 Murthadha Muthahhari, Manusia Sempurna Pandangan Islam Tentang Hakikat Manusia (Jakarta:Lentera, 1994), 1

${ }^{38}$ Murthadha Muthahhari, Dasar-Dasar Epistimologi Islam (Jakarta: Sadra International Institute, 2011), 198-199. 
tidak sehat, akan hanya mempengaruhi aspek diri manuisa yang lainnya, yaiut kesehatan akal, bahkan akhirnya akan berdampak pada kesehatan budi (akhlak). ${ }^{39}$

Dalam pandangan Hamka tentang pendidikan jiwa dan jasad, ia kelihatannya terpengaruh pada pandangan Plato dan Prancis Bacon. Hal ini terllihat dari sandaran teoritis yang dipergunakan dalam karyanya lembaga hidup. Diantaranyaia mengutip pendapat Plato yang menyebutkan, bahwa dalam melaksanakan pendidikan, maka ada dua latihan yang perlu dikembangkan, yaitu: 1) Melatih tubuh dengan gymnastic supaya tubuh kuat dan sehat; 2) Melatih jiwa dengan musik, agar jiwa memperoleh ketentraman dan mampu merasakan sesuatu. Sejalan dengan konsep manusia, maka muatan kurikulum yang harus diberikan kepada peserta didik adalah mata pelajaran yang terkait dengan pengembangan intelektual dan keterampilan, materi yang terkait dengan pengembangan spiritual, materi yang terkait dengan pengembangan emosional, materi yang terkait dengan pengembangan kecerdasan sosialnya, serta materi yang terkait dengan pembinaan fisiknya.

Sehubung dengan berbagai materi tersebut adalah mata pelajaran yang terkait dengan pengembangan intelektual seperti mata pelajaran logika, matematika, fisika dan berbagai ilmu pengetahuan alam lainnya. Selanjutnya yang berkenaan dengan materi yang terakit dengan pengembangan spiritual maka diberikan pelajaran agama, khususnya yang berikatan dengan keimanan, ibadah dan tasawuf. Adapun materi yang terkait dengan pengembangan emosional antara lain, mata pelajaran estetika, sastra, akhlak mulia. Selanjutnya materi yang terkait dengan pengembangan keterampilan, kecerdasan dan kesehatan diberikan mata pelajaran tentang olahraga. ${ }^{40}$

Maka dari itu setiap jenis pendidikan memerlukan dan memiliki kurikulum. Karena kurikulum sudah terencana rapi, akan mempermudah proses pembelajaran dalam mencapai tujuannya. Terkait dengan konsep manusia yang terdiri dari dua dimensi ini, maka kurikulum menurut Murthadha Muthahhari terdapat dalam pelajaran olahraga dan kesehatan. Yakni mengenai dimensi jasmani (jasad) terdapat organ-organ tubuh yang bekerja secara terorganisir untuk kesehatan tubuh. Agar organ tubuh bekerja secara maksimal dan dapat menjalankan fungsinya masing-masing maka perlu asupan gizi dan latihan-latihan yang bisa menjaga kesehatan organ tubuh.

Oleh karenanya penting dalam setiap jenjang pendidikan mulai pendidikan dasar sampai pendidikan menengah atas diberikan pendidikan olahraga. Karena pendidikan olahraga dan kesehatan tidak bisa diabaikan, karena tanpa adanya ilmu tentang olahraga dan kesehatan manusia akan kesulitan menjaga kesehatan tubuhnya. Adanya pengetahuan tentang makanan sehatdan latihan-latihan fisik yang baik dan benar merupakan modal dasar untuk menuju tubuh yang sehat. Tubuh yang sehat merupakan syarat mutlak untuk bisa bersaing dan berjuang demi mendapatkan peran dan fungsi penting dalam persaingan hidup hari ini.

Dalam kurikulum 2013, ditegaskan bahwa peserta didik harus menguasai berbagai kompeteni inti (KI), yaitu sikap spiritual (KI-1), sikap sosial (KI-2), aspek keterampilan dan aspek pengetahuan. Para ahli pendidikan muslim umumnya sependapat bahwa teori dan praktek kependidikan Islam harus didasarkanpada konsepsi dasar tentang manusia. Pembicaraan diseputar persoalan ini adalah merupakan sesuatu

39 Azyumardi Azra, Memperbincangkan Dinamika Intelektual dan Pemikiran HAMKA (Jakarta: Kencana Prenada Media Group, 2008), 124.

${ }^{40}$ Abudin Nata, Filsafat Pendidikan, (Jakarta : 2011), h. 63-64 
yang sangat vital dalam pendidikan. Tanpa kejelasan tentang konsep ini, pendidikan akan meraba-raba. Bahkan menurut Ali Ashraf, pendidikan Islam tidakakan dapat difahami secara jelas tanpa terlebih dahulu memahami penafsiran Islam tentang pengembangan individu seutuhnya. ${ }^{41}$

Fungsionalisasi pendidikan Islam dalam mencapaitujuannya sangat bergantung pada sejauh mana konsep filsafat penciptaan manusia dan fungsi penciptaannya dalam alam semesta ini. Untuk menjawab hal itu, maka pendidikan Islam dijadikan sebagai usaha sarana yang kondusif bagi proses transformasi ilmu pengetahuan dan budaya Islami dari satu generasi kepada generasi berikutnya. Dalm konteks ini difahami bahwa posisi manusia sebagai khalifah dan 'abd menghendaki program pendidikan yang menawarkan sepenuhnya penguasaan ilmu pengetahuan secara totalitas, agar manusia tegar sebagai khalifah dan taqwa sebagai substansi dan aspek 'abd. Sementara itu, keberadaan manusia sebagai resultan dari dua komponen (materi dan imateri) menghendaki pula program pendidikan yang sepenuhnya mengacu pada konsep equilibrium, yaitu integrasi yang utuh antara pendidikan aqliyah dan qalbiyah. ${ }^{42}$

Agar pendidikan umat berhasil dalam prosesnya, maka konsep penciptaan manusia dan fungsi penciptaannya dalam alam semesta harus sepenuhnya diakomondasikan dalam perumusan teori-teori pendidikan Islam melalui pendekatan kewahyuan, empiriskeilmuan dan rasional filosofis. Dalam hal ini harus difahami pula bahwa pendekatan keilmuan dan filosofis hanya merupakan media untuk menalar pesan-pesan tuhan yang absolute, baik melalui ayat-ayat-Nya yang bersifat tekstual (Qur'aniyah), maupun ayat-ayat-Nya yang bersifat kontekstual (Kauniyah) yang telah dijabarkan-Nya melalui sunatullah.

Tugas membangun manusia yang beramal dan berakhlak serta beradab itu diliputi oleh ikhtiar pendidikan. Pendidikanlah yang bertujuan membangun seutuhnya, sebagai pribadi yang mandiri dan sekaligus anggota masyarakat yang bermartabat. Dalam Islam, tujuan mencari pengetahuan pada puncaknya adalah untuk menjadi seseorang manusia yang baik, sehingga system pendidikan dirancang sesuaidengan pencerminan manusia, bukan sekedar manusia, tetapi manusiayang universal, sempurna.

Pada hakikatnya pendidikan Islam mementingkan seluruh aspek tersebut dan ingin mewujudkan segala macam pendidikan secara utuh, karena pendidikan Islam adalah pendidikan manusia seutuhnya. Yaitu akal dan hatinya, rohani dan jasmaninya serta akhlak dan keterampilannya. Itulah keunikan pendidikan Islam dalam hubungannya dengan manusia dengan kesempurnaan dan kelengkapan yang menyeluruh sebagai ciri khas Islam. Pendidikan berpengaruh positif bagi kehidupan manusia. Sebagai contohnya pendidikan melalui pengalaman hidup. Pengalaman seseorang dapat mengetahui baik buruknya suatu tindakan. Akan lebih berhati-hati dalam memilih suatu keputusan. Hal ini sesuai dengan pendapat berikut: pendidikan sebagai kekuatan berarti mempunyai wewenang dan cukup kuat bagi kita, bagi rakyat banyak (khalayak) untuk menentukan satu dunia yang macam apa yang kita inginkan dan bagaimana mencapai dunia semacam itu, dan tidak ada satu fungsi dan jabatan di dalam masyarakat tanpa melalui proses pendidikan baik didalam maupun di luar lembaga formal. Hubungan dan interaksi sosial yang terjadi dalam proses pendidikan di

${ }^{41}$ Ali Ashraf, Horison Baru Pendidikan Islam, (Jakarta: Pustaka Progresif, 1989), h. 1

42 Al-Rasyidin dan Samsul Nizar, Pendekatan Historis, Teoritis dan Praktis, Filsafat Pendidikan Islam, 21-23. 
masyrakat mempengaruhi perkembangan kepribadian manusia. Untuk memperoleh hakekat diri yang makin bertambah sebagai hasil pengalaman berturut-turut sepanjang kehidupan masyarakat.

Menurut Wahyuddin sebagaimana dikutip oleh Dauz Biotekhno "Kesadaran akan pentingnya manfaat pendidikan dapat memberikan prestasi yang intelektual bagi manusia yang terlibat didalamnya. Belakangan ini kesadaran akan manfaat pentingnya pendidikan sebagai penunjang menciptakan sumber daya manusia dirasakan sudah tidak ada lagi. Ketika bukan lagi keutamaan, kasih dan keadilan yang ditanamkan dalam konsep pendidikan, melainkan mencari keuntungan materi dan kekuasan atau adanya komersialisasi di dunia pendidikan, ini akan menjadi sebab utama terjadinya praktik pendidikan diskriminatif".

Apabila dalam kehidupan manusia tidak dibarengi dengan pendidikan otomatis kehidupan manusia itu tidak akan terarah dengan baik, tetapi sebaliknya apabila kehidupan manusia dibarengi dengan pendidikan maka kehidupannya pun akan terarah dan menjadi lebih baik.Ilmu pengetahuan memegang peranan penting dalam kehidupan. Tanpa ilmu, manusia akan buta dalam segalanya. Ada banyak hal yang dapat diambil manfaatnya dari ilmu pengetahuan ini diantaranya yaitu manfaat adanya ilmu pengetahuan dan teknologi. Dengan adanya ilmu tersebut, manusia dapat menemukan lampu, komputer, televisi, dan lain-lain.

Berdasarkan rumusan diatas, dapat dipahami bahwa pendidikan Islam merupakan proses membimbing dan membina fitrah peserta didik secara maksimal dan bermuara pada terciptanya pribadi peserta didiksebagai muslim (al-insan al-kamil). Melalui sosok pribadi yang demikian, peserta didik diharapkan akan mampu memadukan fungsi iman, ilmu dan amal secara integral bagi terbinanya kehidupan yang harmonis, baik dunia maupun akhirat.

\section{Kesimpulan}

Berdasarkan penelitian yang telah penyusun lakukan, maka dapat disimpulkan sebagai berikut: Pertama, konsep manusia menurut Murthadha Muthahharibahwa Manusia adalah makhluk yang unik, rasional, bertanggung jawab, dan memiliki kecerdasan yangtidak bisa disamakan oleh binatang karena manusia mampu menyadari bahwa tanggunng jawab terhadap tindakan-tindakan yang dilakukannya dan melihat kemampuan manusia lebih tinggi daripada binatang. Manusia bukan saja digerakan oleh dorongan biologis saja, tetapi juga oleh kebutuhan untuk mengembangkan dirinya sampai bentuk yang ideal untuk memenuhi dirinya dan manusia dilahirkan tidak mengetahui sesuatu apapun, dan Allah memberikan manusia pengelihatan, pendengaran, akal dan hati yang digunakan untuk membekali kehidupannya menjadi manusia yang baikdan bersyukur; Kedua, hubungan antara konsep manusia dengan tujuan pendidikan adalah hubungan yang sangat erat, karena keduanya mempunyai ikatan yang tidak dipisahkan antara satu dengan yang lainnya. Tujuan Pendidikan adalah menumbuhkan pola kepribadian yang sempurna guna menjadi muslim yang sebenarnya dan menjadikan manusia yang sungguh-sungguh Islami dengan begitu jalan hidupnya menjadi terang dan jelas. Melalui pendidikan manusia dapat mengembangkan kepribadiannya dengan diarahkan kepada yang lebih baik. Manusia muslim yang pintar secara intelek dan terpuji secara moral menjadikan manusia seimbang dan sempurna yang didasari dengan dua dimensi utama yakni jasmani dan rohani. Maksud dari pribadi 
yang sempurna dengan jasmani dan rohani adalah dimana pendidikan tidak hanya memenuhi kebutuhan jasmani seperti memberikan pendidikan dengan tujuan memiliki penghasilan yang besar, namun pendidikan juga harus memenuhi kebutuhan rohani kebahagiaan dalam hidup, karena dengan ilmunya seseorang mampu bersosialisasi dengan orang lain sehingga ia mampu memberikan manfaat umumnya bagi lingkungan dan khususnya untuk diri sendiri menjadi pribadi yang beriman kepada Tuhannya. Selain hal tersebut tujuan pendidikan lainnya adalah membentuk kepribadian manusia yang utuh melalui latihan kejiwaan, kecerdasan otak, penalaran, perasaan dan indra.

\section{DAFTAR PUSTAKA}

Abu al-Ainain, Ali Khalil. Falsafah al-Tarbiyah al-Islamiyah fi Qur'an al-Karim, Mesir: Dar alFikr al'Arabiyah, 1980.

Al-Syathibi, Imam. Syarh al-Muwafaqat, Beirut: Dar al-Fikr, 1958.

Amini, Ibrahim. Asupan Ilahi, Jakarta: Al-Huda, 2011.

'Ammarah, Muhammad dan Muhammad 'Abduh Al-Imam: Mujaddid al-Islam, Beirut: Almuassassah al-Islamiyyah li al-Dirasah wa al-Nasyr, 1981.

Arifin, M. Ilmu Pendidikan Islam: Suatu Tinjauan Teoritis Dan Praktis Berdasarkan Pendekatan Interdisipliner, Jakarta: Bina Aksara, 1991.

Ashraf, Ali. Horison Baru Pendidikan Islam, Jakarta: Pustaka Progresif, 1989.

Asy'ari, Musa. Filsafat Islam Sunnah Nabi Dalam Berfikir, Yogyakarta: Lesfi, 1999.

Athiyah al-Abrasy, Muhammad. Dasar-dasar Pokok Pendidikan Islam. (terj). Bustami A. Gani dan Djohar Bahry, Jakarta: Bulan bintang, 1974.

Azra, Azyumardi. Memperbincangkan Dinamika Intelektual dan Pemikiran HAMKA, Jakarta: Kencana Prenada Media Group, 2008

Bagir, Haidar. Murtadha Muthahhari Sang Mujahid, Bandung: Yayasan Muthahhari, 1988

Bouman, P.J. Sosiologi Pengertian dan Masalah, Jakarta: Kanisius, 1971.

D Marimba, Ahmad. Pengantar Filsafat Pendidikan Islam, Bandung: Al-Ma'rif, 1989.

Drajat, Zakiyah., dkk. Ilmu Pendidikan Islam, (Jakarta: Bumi Aksara, 2004.

Faqih, Abdul Latif. Rahasia Segitiga: Menyempurnakan hidup dengan Surah An-Nas, Jakarta: Hikmah, 2008.

Hasbullah, Kapita Selekta Pendidikan Islam, Jakarta: PT Raja Grafindo Persada, 1996.

Hidayatullah, Pemikiran Teologis Murtadha Muthahhari Tentang Keadilan Tuhan, Bandar Lampung: Perpustakaan Ushuluddin UIN RIL, 1999.

Jalaluddin, Filsafat Pendidikan, Manusia Filsafat dan Pendidikan, Jakarta: Radar Jaya Offset, 2002

Jalaludin, Teologi Pendidikan, Jakarta: PT Raja Grafindo Persada, 2001.

Jalaluddin dan Said, Usman. Filsafat Pendidikan Islam, Konsep dan Perkembangan Pemikirannya, Jakarta: PT Raja Grafindo Persada, 1996.

Jamali, dkk, Membedah Nalar Pendidikan Islam, Jakarta : Pustaka Rihlah, 2005.

Koentjaraningrat, Pengantar Ilmu Antropologi, Jakarta: Rineka Cipta, 1990.

Labib, Muhsin. Para Filosof; Sebelum dan Sesudah Mulla Sadra, Jakarta: al-Huda, 2005.

Langgulung, Hasan. Asas-asas Pendidikan Islam, Jakarta: PT Al-Husna, 1998.

Langgulung, Hasan. Manusia \& Pendidkan; Suatu Analisa Psikologis, Filsafat, dan pendidikan, Jakarta: PT. Pusaka Al-Husna Baru, 2004.

Mastuhu, Sistem Pendidikan Nasional Visioner, Jakarta: Lentera Hati, 2007.

Mubarok, Achmad. Psikologi Dakwah, Jakarta: Pustaka Firdaus, 2002. 
Muhaimin, Pengembangan Kurikulum Pendidikan Agama Islam, Jakarta: PT. Raja Grafindo Persada, 2007.

Munir Mursi, Muhammad. at-Tarbiyah al-Islamiyah Usuluha wa Tatawwuruha fi Bilad alArabiyah, Qahhirah: Alam al-Kutub, 1997.

Muthahhari, Murtadha. Bedah Tuntas Fitrah, Jakarta: Citra, 2011.

Muthahhari, Murtadha. Bimbingan Untuk Generasi Muda, Jakarta: Sadra International Institute, 2011.

Muthahhari, Murtadha. Ceramah-ceramah Seputar Persoalan Penting Agama dan Kehidupan, Jakarta: Lentera, 1999.

Mutahhari, Murtadha. Dasar-dasar Epistemologi Pedidikan Islam, Jakarta: Sadra Internasional Instutie, 2011.

Muthahhari, Murtadha. Keadilan Ilahi; Asas Pandangan Dunia Islam, Terj: Agus Efendi, Bandung: Mizan, 1995.

Muthahhari, Murtadha. Man and Universe, Qum: Ansariyan Publication, $1401 \mathrm{H}$.

Muthahhari, Murtadha. Manusia Sempurna Pandangan Islam Tentang Hakikat Manusia, Jakarta: Lentera, 1994

Muthahhari, Murtadha. Mengenal Epistimologi, Sebuah Pembuktian Terhadap Rapuhnya Pemikiran Asing dan Kokohnya Pemikiran Islam, Jakarta: Lentera, 2008.

Muthahhari, Murtadha. Pengantar Pemikiran Shadra: Filsafat Hikmah, terj: Tim penerjemah Mizan, Bandung: Mizan, 2002.

Muthahhari, Murtadha. Perspektif Al-Quran Tentang Manusia dan Agama, Bandung: Mizan, 1998.

Nata, Abuddin. Ilmu Pendidikan Islam, Jakarta: Kencana Prenada Group, 2012.

Nata, Abuddin. Filsafat Pendidikan, Jakarta: 2011.

Nata, Abuddin. Metode Study Islam, Jakarta: PT Grafindo Persada, 2001.

Nata, Abuddin. Pendidikan dalam Perspektif Al-Qur'an, Jakarta: Buku Daras, 2005.

Nawawi, Hadari. Metode Penelitian Sosial, Yogyakarta: Gajah Mada Univer Pers, 1998.

Poerwadaminta, W.J.S. Kamus Umum Bahasa Indonesia, (Jakarta: Balai Pustaka, 1994.

Putra Daulay, Haidar. Pendidikan Islam Dalam Perspektif Filsafat, Jakarta: Kencana Prenadamedia Group, 2014.

Raharjo, M. Dawam. Konsepsi Manusia Menurut Islam, Jakarta: Grafitti Press, 1987.

Rahman, Fazlur. Al-Islam, Jakarta: Bulan Bintang, 1987.

Ramayulius, Metodelogi Pengajaran Agama Islam, Jakarta: Kalam Mulia, 1990.

Saleh, Hairus. filsafat Manusia Studi Komparatif antara Abdurrahman Wahid dan Murtadha.

Samsul Nizar, Al-Rasyidin. Filsafat Pendidikan Islam, Jakarta: Ciputat Press, 2005.

Samsul Nizar, Al-Rasyidin. Pendekatan Historis, Teoritis dan Praktis, Filsafat Pendidikan Islam, Jakarta: PT Ciputat Press, 2005.

Shihab, Quraish. Tafsir Al-Misbah, Jakarta: Lentera Hati, 2002.

Shihab, Quraish. Wawasan Al-Qur'an: Tafsir Maudhu'i Atas Pelbagai Persoalan Umat, Bandung: Mizan Media Utama, 2001.

Sobah, Izkar. Kejahatan dan Keadilan Tuhan Dalam Perspektif Teologi Murtadha Muthahhari, Aqidah Filsafat: Fakultas Ushuluddin dan Filsafat, 2006

Soebahar, Abd Halim.Wawasan Baru Pendidikan Islam, Jakarta: Kalam Mulia, 2002.

Soerjono, dkk., al-Qur'an dan terjemahannya, Seamarang: Toha Putra, 1989.

Subagyo, P Joko. Metodologi Penelitian Teori dan Praktek, Jakarta: Rhineka Cipta, 1991. 
Sugono, Dendy. Kamus Besar Bahasa Indonesia pusat Bahasa, Jakarta: PT Gramedia Pustak Utama, 2008.

Suhartoni, Supalan. Filsafat Pendidikan, Jogjakarta: Ar-Ruzz Media Group, 2007.

Suharsono, melejitkan IQ, IE, dan IS, Jakarta: Inisiasi Press, 2002.

Sukmadinata, Nana Syaodih. Landasan Psikologi Proses Pendidikan, Jakarta: 2009.

Surahmad, Winarno. Pengantar Penelitian Ilmiah, Dasar Metode Teknik, Bandung: Tarsito, 1990. Syam, Muhamad Noor. Filsafat Kependidikan dan Dasar Filsafat Kependidikan Pancasila

Syamsuri, Manusia Sempurna Perspektif Murtadha Muthahhari, Penelitian Dosen Fakultas Ushuluddin dan Filsafat, UIN, 2001.

Syukur, Amin. Pengantar Studi Islam, Semarang: Bima Sejati, 2000.

Tafsir, Ahmad. Ilmu Pendidikan Dalam Perspektif Islam, Bandung: PT Remaja Rosdakarya, 2007.

Uhbiyati, Nur. Ilmu Pendidikan Islam, Bandung: CV. Pustaka Setia.

Yasin, A. Fatah. Dimensi-dimensi Pendidikan Islam, Yogyakarta : UIN Malang Press, 2008

Zuhairini, dkk, Filsafat Pendidikan Islam, Jakarta: Bumi Aksara, 1994. 